\title{
MANAGERIAL PERFORMANCE: THE MEDIATING ROLE OF STRATEGY MANAGEMENT ACCOUNTING TECHNIQUES ON COMPETITIVE ADVANTAGE AND ORGANIZATION PERFORMANCE
}

\author{
Listya Sugiyarti*, Nur Asmilia \\ Universitas Pamulang \\ *listya.sugiarti@unpam.ac.id
}

\begin{abstract}
This study aims to examine Managerial Performance as Strategic Management Accounting Technique for Competitive Advantage and Organization Performance in banking companies in the Tangerang region, Indonesia. In this study utilizing primary data in the form of questionnaires distributed to managers in banking companies in Tangerang region, Indonesia. This study applied Structure Equation Modeling analysis techniques with Amos software program tools, while a number of respondents are 73 managers. From the results of the tests which have been obtained that Managerial Performance as Strategic Management Accounting Techniques had a positive and significant effect on Competitive Advantage. There was not significant effect of Competitive Advantage on Organization Performance, and Managerial Performance as Strategic Management Accounting Techniques did not have a positive and significant effect on Organization Performance in banking companies in Tangerang Region.
\end{abstract}

Keywords: Manager Performance; Strategic Management Accounting Techniques; Competitive Advantage; Organization Performance

\section{INTRODUCTION}

In achieving the success of companies that have high competitiveness, companies need to implement different strategies and manager's performance as indicators of manager's success to realize the expected goals (Hidayat \& Muliasari, 2020). From time to time the manager's performance improvement can be sought in the decision process. In the decision making process, managers utilize their information and interpretation skills to make effective decisions.
According to the theory of Bounded Rationality Theory (Simon, 1978) as decision makers is limited by several obstacles in making rational and effective decisions. These constraints, including 1) limited availability of information, 2) limited capacity of the human mind and 3) limited amount of time to make decisions, have made managers very rational in the decisionmaking process.

To prevent dysfunctional decision making caused by limited rationality, managers need special skills to enable them to use information correctly. A set of skills that enable 
EAJ (Economics and Accounting Journal) - Vol. 3, No. 2, May 2020 - Sugiyarti \& Asmilia

individuals to recognize information, identify information, utilize and interpret information is called information literacy (Mishra and Mishra, 2010). Information literacy skills will enable managers to utilize, evaluate, organize, integrate, and interpret information critically and correctly in problem solving (Doyle, 1992). By having these skills, managers will be able to use information effectively and thus will enable them to make effective and appropriate decisions. Rational and appropriate decisions will allow managers to solve problems in carrying out managerial functions and thus improve their managerial performance.

Strategy Management

Accounting is the provision and analysis of management accounting data about the business and its competitors, to be used in developing and monitoring business strategies (Simmonds, 1981). Broomwich (1990) defines Strategic Management Accounting (SMA) as providing and analyzing financial information on the company's product market and competitor costs and the cost structure and monitoring of company strategy and its competitors in this market for several periods.

Previous research has proven that the use of Strategic Management Accounting has a positive impact on managerial performance and organizational performance. Ah Lay and Jusoh (2011) found that the use of Strategic Management Accounting improves the relationship between strategy and organizational performance. Zenita (2012), found that information literacy and Strategic Management Accounting have a positive influence on managerial performance. The analysis of mediation effects conducted by Zenita (2010) also found that Strategic Management Accounting mediates the relationship between information literacy and managerial performance. Several other studies on managerial performance and self-efficacy have also been conducted (Katarina, 1993; Gul \& Chia, 1994; Chia 1995) but there is still a lack of studies conducted in examining the relationship between information literacy, self-efficacy, Strategic Management Accounting and managerial performance.

Other studies support the direct effects of information literacy, selfefficacy and the use of Strategic Management Accounting information on managerial performance. Further analysis of the mediating effects of the use of SMA information shows that Strategic Management Accounting mediates the relationship between information literacy and managerial performance. The findings of this study also show that the effect of the use of Strategic Management Accounting information on managerial performance is reinforced by self-efficacy (Raisya, Ria, Rita and Jamaliah, 2015).

The contribution of this study aims to examine the effect of Managerial performance as Strategy Management Accounting on Competitive Advantage and Organization Performance. In addition, this study also intends to test the mediating effect of Competitive Advantage for the relationship between Managerial performance as a Strategy Management Accounting and organization performance.

The results of this study are expected to provide additional insights related to Managerial performance, Competitive Advantage and Strategy Management Accounting. For managers, the results of this study are expected to encourage managers to improve Managerial performance as Strategy Management Accounting and Competitive Advantage. For business organizations, the results of this study are expected to provide information on Strategy Management Accounting as the basis for the decision making process. 
EAJ (Economics and Accounting Journal) - Vol. 3, No. 2, May 2020 - Sugiyarti \& Asmilia

\section{LITERATURE REVIEW}

2.1 Managerial Performance as Strategic Management Accounting Techniques with Competitive Advantage

Tornow and Wiley, 1991; Waldman, 1994; Madu et al., 1995 explained the concept of TQM as follows: "TQM is generally described as a collective, interlinked system of quality management practices that are associated with organizational performance". The concept above is intended that TQM in general is to describe a system that is collective (comprehensive), where the system is related to the implementation of quality management to realize good corporate performance. Therefore, TQM is a system that aims to improve the performance of the company as a whole by improving the quality of management.

Managerial Performance is a management strategy in a company that is a place that can see the best view of the activities and potential of existing competitors with the aim of creating added value and improving the company's operations (Rita, at al., 2014). Managerial Performance is fundamental to pursuing competitive advantage and competitive advantage is the heart of organization performance (Rita, at al., 2014). Thus, when a company produces good financial returns in the industry, in the long-term, the company experiences competitive advantages over its competitors. From the study literature above, the researcher sets the first hypothesis as follows:

H1: Managerial Performance as Strategic Management Accounting Techniques has a positive effect on Competitive Advantage.

\subsection{Managerial Performance as Strategic Management Accounting Techniques with Organization Performance}

Managerial Performance in organizations is very important to create a strong information base in making appropriate strategic decisions and achieving good organizational performance (Rita, at al., 2014). Managerial Performance is fundamental to pursuing competitive advantage and competitive advantage is the heart of organization performance (Rita, at al., 2014).

According to Heinen \& Hoffjan (2005) the effectiveness of increasing competitive analysis also has a positive effect on organization performance. The results of the study confirm the findings of Subramanian \& Ishak (1998) that companies that have sophisticated systems to monitor the activities of their competitors show greater profitability than companies that do not have the system. Akenbor \& Okoye, (2011) found that Managerial Performance has a positive effect on company profitability. Organization Performance is evidence of the results of organizational members measured in terms of income, profit, growth, development and expansion of the organization (Ejere \& Abasilim, 2012).

$\mathrm{H}_{2}$ : Managerial Performance as a Strategic Management Accounting Techniques has a positive effect on Organization Performance.

\subsection{Competitive Advantage with Organization Performance}


EAJ (Economics and Accounting Journal) - Vol. 3, No. 2, May 2020 - Sugiyarti \& Asmilia

According to Munizu, (2013) stated that the results of the study showed that organizational performance was more influenced by competitive advantage. With the existence of competitive advantages make organization performance better than existing competitors. Competitive Advantage is an advantage possessed by the company, which exceeds its competitors. These advantages can be in the form of giving higher value to customers with lower prices or additional benefits and better services (Ehmke, 2011). In the Kaliappen \& Hilman study, (2013) it was shown that the cost leadership strategy had a significant influence on organizational performance. Competitor focused accounting is fundamental to pursue competitive advantage and competitive

\section{RESEARCH METHOD}

\subsection{Research Design}

The data used in this study are

Table l: Operational Variable

\begin{tabular}{|c|c|c|c|}
\hline $\mathrm{N}_{0}$ & Variable & Definition & Indicator \\
\hline 1 & $\begin{array}{l}\text { Manager } \\
\text { Performance } \\
\text { Strategic } \\
\text { Management } \\
\text { Accounting }\end{array}$ & $\begin{array}{l}\text { Managerial Performance is a management } \\
\text { strategy in a company that is a place that can } \\
\text { see the best view of the activities and } \\
\text { potential of existing competitors with the aim } \\
\text { of creating added value and improving the } \\
\text { company's operations (Rita, at al., 2014) }\end{array}$ & $\begin{array}{l}\text { 1.Strategic Cost } \\
\text { Management } \\
\text { 2.Strategic Pricing }\end{array}$ \\
\hline 2 & $\begin{array}{l}\text { Competitive } \\
\text { Advantage }\end{array}$ & $\begin{array}{l}\text { Competitive Advantage is an advantage } \\
\text { possessed by the company, which exceeds its } \\
\text { competitors. These advantages can be in the } \\
\text { form of giving higher value to customers with } \\
\text { lower prices or additional benefits and better } \\
\text { services (Ehmke, 2011). }\end{array}$ & $\begin{array}{l}\text { 1.Cost Leadership } \\
\text { 2. Diffrentiation }\end{array}$ \\
\hline 3 & $\begin{array}{l}\text { Organization } \\
\text { Performance }\end{array}$ & $\begin{array}{l}\text { Organization Performance is evidence of the } \\
\text { results of organizational members measured } \\
\text { in terms of income, profit, growth, } \\
\text { development and expansion of the } \\
\text { organization (Ejere \& Abasilim, 2012) }\end{array}$ & $\begin{array}{l}\text { 1.Financial Perspective } \\
\text { 2.Customers Perspective } \\
\text { 3. Innovation and } \\
\text { LeamingPerspective } \\
\text { 4. Intemal business } \\
\text { Perspective }\end{array}$ \\
\hline
\end{tabular}

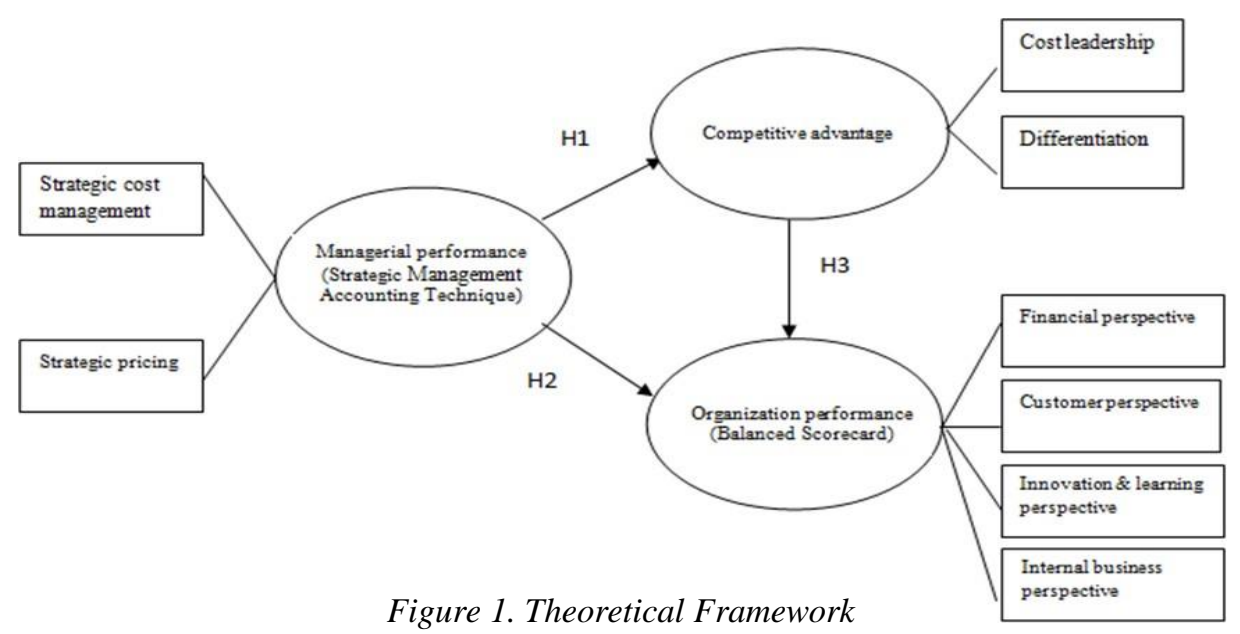

advantage is the heart of organization performance (Rita, at al., 2014). Besides that, Majeed (2011) supports the existence of a relationship between competitive advantage and organization performance. From this implication, this research raises the following hypothesis:

$\mathrm{H}_{3}$ : Competitive Advantage has a positive effect on the Organization. primary data obtained from managers of banking branch offices consisting of the Main Branch Office and Sub-Branch Offices in the Tangerang region, Indonesia. The data analysis technique used by the researcher is Structure Equation Modeling with the Amos 22 software program. Determination of the sample in this study was conducted using a purposive sampling method in accordance with the criteria by distributing questionnaires to the 
EAJ (Economics and Accounting Journal) - Vol. 3, No. 2, May 2020 - Sugiyarti \& Asmilia

managers of the Main Branch Banking Office and Sub-Branch Office.

\subsection{Sample}

The sample in this study was taken from the number of banking companies in Tangerang that could be included in the criteria were 31 companies (32 Main Branch Offices and 155 Sub-Branch Offices). Questionnaires spread of 93 sent to Managers and as many as 73 questionnaires were returned until later used for the final analysis.

\subsection{Operational Definition}

\section{RESULTS AND DISCUSSION \\ 4.1 Demographics Detail of Respondents and Statistics Variables}

In Table 2 presents the details of the respondents' demographics. In general, the respondents of this study had a good educational background as many as $64 \%$ had a bachelor's degree. $84 \%$ of respondents are experienced managers, with more than five years of work experience. The respondents already have enough knowledge and experience to be implemented in their day-to-day work activities.

\begin{tabular}{|l|c|c|}
\hline \multicolumn{1}{|c|}{ Respondent Demographic Details } \\
\hline $\begin{array}{l}\text { Gender: } \\
\text { Woman }\end{array}$ & Frequency & Percentage \\
Man & 39 & \\
\hline Age (year): & 34 & $53 \%$ \\
\hline 21 to 30 & & $47 \%$ \\
\hline 31 to 40 & 5 & $7 \%$ \\
\hline 41 to 50 & 27 & $37 \%$ \\
\hline$>50$ & 34 & $47 \%$ \\
\hline Last education: & 7 & $10 \%$ \\
\hline Senior High School & & \\
\hline Diploma & 0 & $0 \%$ \\
\hline Strata One & 21 & $29 \%$ \\
\hline Magister & 47 & $64 \%$ \\
\hline Doctorate & 5 & $7 \%$ \\
\hline Work experience: & 0 & $0 \%$ \\
\hline Less than 5 years & & \\
\hline More than 5 years & & \\
\hline
\end{tabular}

Source: Results of data processing 
EAJ (Economics and Accounting Journal) - Vol. 3, No. 2, May 2020 - Sugiyarti \& Asmilia

In Table 2, shows that as many as 39 respondents $(53 \%)$ were women and as many as 34 respondents (47\%) were men. This explains that the respondents who became branch heads were dominated by women. Of the 73 respondents who were the majority of respondents aged 41 to 50 years, there were 34 respondents (47\%). This explains the number of branch heads coming from unproductive age groups. And the majority of respondents with S1 final education were 47 respondents (64\%) then followed by Diploma education background of 21 respondents $(29 \%)$. Of the 73 respondents who became the majority of the work experience of respondents more than 5 years as head of the branch then followed by branch heads less than 5 years as many as 12 respondents (16\%). This shows that the head of the branch already has enough knowledge and experience to be implemented in his day-to-day work activities.

\subsection{Hypothesis Testing}

The testing process is carried out by a structural model which includes two main parts, namely the overall model goodness of fit of the structural model and hypothesis testing.

\section{Testing the Overall Goodness of Fit}

The results of this test are measured through several measurement indices namely ChiSquare, Probability, RMSEA, CFI, NFI, TLI and CMIN. Following is Table 3 which is the result of testing the goodness of fit model Overall:

2. Goodness of Fit Structural Model Testing Results
Based on the modeling of the variables studied can be seen in table 3 below:

Table 3: index models

\begin{tabular}{|c|c|c|c|}
\hline Criteria & Result & $\begin{array}{l}\text { Cut of } \\
\text { Value }\end{array}$ & $\begin{array}{c}\text { Model } \\
\text { Assessment }\end{array}$ \\
\hline $\begin{array}{l}\text { Chi- } \\
\text { Square }\end{array}$ & 14.434 & $\begin{array}{c}\text { It is } \\
\text { expected to } \\
\text { be smaller }\end{array}$ & Good \\
\hline Probability & 0,636 & $\geq 0,05$ & Good \\
\hline $\begin{array}{l}\text { RMSE } \\
\text { A }\end{array}$ & 0,000 & $\leq 0,08$ & Good \\
\hline NFI & 0,891 & $\geq 0,90$ & $\underset{1}{\text { Margina }}$ \\
\hline TLI & 1,056 & $\geq 0,95$ & Good \\
\hline CFI & 1,000 & $\geq 0,94$ & Good \\
\hline
\end{tabular}

Based on table 3 above shows that the model has met all the measurement criteria or index models. The calculation result of Chi-square is 14,434. Can be said to be good because it fulfills the assumption of multivariate normality.

While the RMSEA value based on the above table is equal to 0,000 , the value is below the value range of 0,08 . Then for the NFI value of 0,891 , the TLI value is 1,056 and the value of CFI 1,000 is still above the cut-off value. The model can be said to be good so that the model is feasible to be used in testing the hypothesis. 
EAJ (Economics and Accounting Journal) - Vol. 3, No. 2, May 2020 - Sugiyarti \& Asmilia

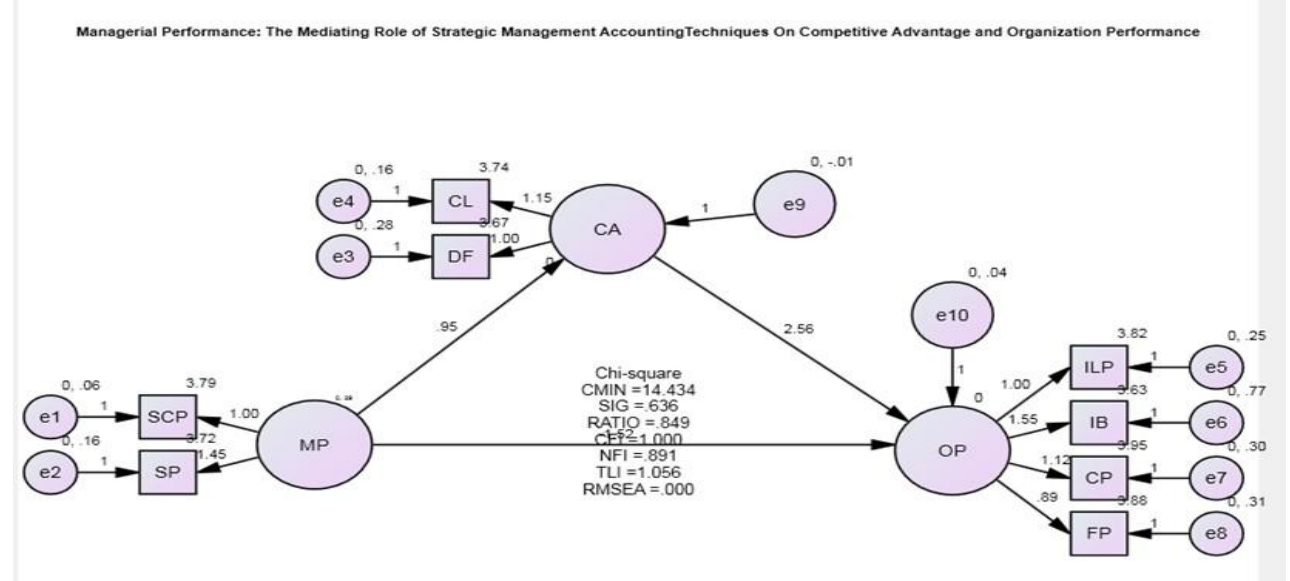

3. Regression Weights Test Results

The last test after testing overall model goodness of fit of the structural model is hypothesis testing. The results of the study hypothesis testing are shown in table 4 below:

Table 4: Hypothesis Testing

Hypothesis Testing

\begin{tabular}{|c|c|c|c|c|}
\hline & Estimate S.E. & C.R. & $P$ & Decision \\
\hline $\mathrm{CA}<\ldots$ & $\begin{array}{ll}.948 & .273\end{array}$ & 3.477 & $8 * 8$ & Influenced \\
\hline$O P<\ldots A$ & 2.555 & .346 & .729 & Un Influenced \\
\hline$O P<M P$ & -1.515 & .222 & .825 & Un Influenced \\
\hline
\end{tabular}

Source: Data processed

Hypothesis accepted in this research is $\mathrm{H} 1$. The hypothesis rejected in this study are $\mathrm{H} 2$ and H3.

\subsection{DISCUSSION}

Hypothesis testing aims to determine the causality relationship between exogenous variables and endogenous variables in a study.

Managerial performance probability value as Strategic Management Accounting Techniques for competitive advantage is 0,000 because (p) $<0.05$ then the pathway is significant. So the hypothesis that managerial performance as Strategic Management Accounting Techniques has a significant influence on competitive advantage. This is proven because a performance manager who has a good Strategy Management Accounting will be able to pursue a good competitive advantage. This is in line with what was stated by (Rita, al., 2014), which states that Managerial Performance is fundamental to pursuing competitive advantage and competitive advantage is the heart of an organization performance. Thus, when a company produces good financial returns in the industry, in the long run, the company experiences competitive advantages over its competitors.

The magnitude of the influence of managerial performance as Strategic Management Accounting Techniques on organization performance is 0,825 . Where the managerial performance probability value as Strategic Management Accounting to organization performance is 0,825 because $(p)>0.05$ then the path is not significant. So the hypothesis that managerial performance as Strategic Management Accounting Techniques does not have a significant influence on organization performance.

The value of the probability of competitive advantage to organization performance is 0,729 because $(p)>0.05$ then the pathway is not significant. So the hypothesis that competitive advantage does not have a significant influence on organization performance.

This happens because it is possible for the sample from this study 
EAJ (Economics and Accounting Journal) - Vol. 3, No. 2, May 2020 - Sugiyarti \& Asmilia

to be managers of conventional and sharia banking, where it is known that there are some differences in the company's strategy and competitive advantage to get a good organization performance. But is not in line with Munizu, (2013) who stated that the results of the study showed that organizational performance was more influenced by competitive advantage. With the existence of competitive advantages make organization performance better than existing competitors. In the Kaliappen \& Hilman study, (2013) it was shown that cost leadership strategies had a significant influence on organization performance. Besides that, Majeed (2011) supports the existence of a relationship between competitive advantage and organization performance.

\section{CONCLUSION}

This research was conducted on 73 respondents from the main branch office managers and sub-branch office managers. Descriptive analysis shows that respondents believe that managerial performance as good Strategic Management Accounting Techniques will make a good competitive advantage as well, with a competitive advantage to make an organization performance better than existing competitors. Based on descriptive analysis that education from managers who are good respondents and are experienced managers and already have enough knowledge and experience that will be implemented in their day-today work activities even though the productive age is lacking. Based on data quality testing, all research variables are varied and valid. This study found that managerial performance as Strategic Management Accounting Techniques significantly and positively affects competitive advantage. This study found that competitive advantage weakened the relationship between managerial performance as Strategic Management Accounting Techniques and organization performance. Other findings from this study are managerial performance as Strategic Management Accounting Techniques that do not affect organization performance.

The results of this study have limited respondents due to constraints obtained by researcher, the limitations of respondents who only obtained 73 due to limited time in the distribution of questionnaires, the expectations of researcher at least 100 respondents were obtained from 187 respondents. First, not all respondents in this study were met by researchers in terms of filling out the questionnaires, the questionnaires did not use Google forms or similar media. Therefore, the generalization of this research is limited. Subsequent research can replicate this research by using media such as Google Form or similar media in order to get more respondents according to the expectations of researchers. Second, this study uses a questionnaire on managerial performance in banking companies whose strategies have differences between conventional and sharia banks that might present a bias, especially in measuring competitive advantage. Third, this research only focuses on managerial performance variables as Strategic Management Accounting Techniques, competitive advantages, organization performance. Future studies can add other related variables. Future research can also use other software such as STATA software.

\section{REFERENCES}

Ah Lay, T., Jusoh, R. (2011). Business Strategy, Strategic Role of Accountant, Strategic Management Accounting and 
EAJ (Economics and Accounting Journal) - Vol. 3, No. 2, May 2020 - Sugiyarti \& Asmilia

Their Links to Firm Performance: An Explotary Study of Manufacturing Companies in Malaysia. Accounting Research and Education University Teknologi MARA1-27

Akenbor, C.O. \& E.I. Okoye, (2011). Competitor accounting and corporate profitability of manufacturing firms in Nigeria. ESUT Journal of Management Sciences, 6(1), 1-13

Cadez, S. \& Guilding, C. (2008). An exploratory investigation of an integrated contingency model of strategic management accounting. Accounting, Organizations and Society, 33(7/8), 836-863

Cadez, S. \& Guilding, C. (2008). Strategy Strategic Management Accounting : An Investigation of Organizational Configuration. Manchester Business School Research Seminar

Choi, T. Y., \& Eboch, K. (1998). The TQM paradox: relations among TQM practices, plant performance, and customer satisfaction. Journal of Operations management, 17(1), 59-75.

Doyle,C.S. (1992). Outcome Measures for Information Literacy within The National Educational Goals of 1990. Final Report to the National Forum on Information Literacy. National Forum on Information Literacy. Flagstaff

Heinen, C. \& Hoffjan, A. (2005). The strategic relevance of competitor cost assessment - An empirical study of competitor accounting. Journal of Applied Management Accounting Research, 3(1). 17-34

Hidayat, A., \& Muliasari, R. (2020). Pengaruh Likuiditas, Leverage dan Komisaris Independen Terhadap Agresivitas Pajak Perusahaan. SULTANIST: Jurnal Manajemen dan Keuangan, 8(1), 28-36.
Hidayat, A., \& Sadewa, P. (2020). Pengaruh Penggunaan Aplikasi Eviews Terhadap Sikap Belajar dan Kemampuan Pemecahan Masalah Statistik. Edumaspul: Jurnal Pendidikan, 4(1), 321328.

Katarina, D. (1993). Korelasi antara self efficacy dengan kinerja tugas Karyawan Bagian Pengelasan di Divisi G.E.PT.PAL Indonesia Surabaya, Unpublish Thesis. Fakultas Psikologi, Universitas Airlangga, Surabaya

Kaliappen, N., \& Hilman, H. (2013). Enhancing organizational performance through strategic alignment of cost leadership strategy and competitor orientation. Middle-East Journal of Scientific Research, 18(10), 1411-1416

Lord, R. 1996. Strategic Management Accounting: The Emperor's New Cloths? Management Accounting Research. 7(3), 347-366

Majeed, S. (2011). The Impact of Competitive Advantage on Organizational Performance, European Journal of Business and Management, 3(4), 191-196

Mishra, R.N., Mishra, C. (2010). Relevance Information Literacy in Digital Environment. Journal of Emerging Trends In Computing and Informatin Sciences 1(1), 4854.

Munizu, M. (2013). The Impact of total quality management practices towards competitive advantage and organizational performance: Case of fishery industry in South Sulawesi Province of Indonesia. Pakistan Journal of Commerce and Social Sciences (PJCSS), 7(1), 184-197.

Raisya Zenita, Ria Nelly Sari, Rita Anugerah , Jamaliah Said (2015). The Effect of Information Literacy on Managerial Performance: The Mediating Role of Strategic 
EAJ (Economics and Accounting Journal) - Vol. 3, No. 2, May 2020 - Sugiyarti \& Asmilia

Management Accounting and the Moderating Role of Self Efficacy. Accessed at (http://creativecommons.org/license s/by-nc-nd/4.0/), published by Elsevier, 199-205

Rita, C.N., Amaechi E.P., \& Nwekemezie, O.A. (2014). Adoption of Competitor Focused Accounting Methods in Selected Manufacturing Companies in Nigeria. Asian Journal of Economic Modelling, 2 (3), 128-140

Simmon, H.A. (1978). Rationality as Process and as Product of Thought. The American Economic Review 68(2), 1-16

Simmonds, K. (1981). Strategic Management Accounting. Management Accounting 59(4), 2029

Subramanian, R., \& IsHak, S. T. (1998). Competitor analysis practices of US companies: An empirical investigation. MIR: Management International Review, 7-23.

Sugiono. (2004). Konsep, Identifikasi, Alat Analisis dan Masalah Penggunaan Variabel Moderator. Jurnal Studi Manajemen dan Organisasi,1(2): 61-70.

Zenita, R. (2012). Pengaruh Literasi Informasi Terhadap Kinerja Manajerial dan Akuntansi Manajemen Strategis Sebagai Variabel Mediasi.Unpublish Thesis, Universitas Riau: Fakultas Ekonomi 